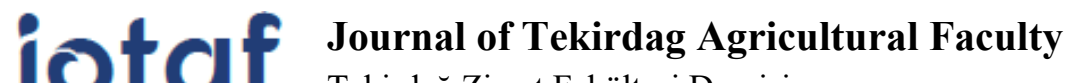

Tekirdağ Ziraat Fakültesi Dergisi

\section{Beyşehir Gölü Milli Parkında Seyahat Maliyetini Etkileyen Faktörlerin Analizi}

Analysis of Factors Affecting Travel Costs in Beyşehir Lake National Park

\section{Zuhal KARAKAYACI ${ }^{1 *}$, Özer KARAKAYACI ${ }^{2}$, Ahmet Tuğrul POLAT ${ }^{3}$}

\section{Öz}

Milli parklar sahip olduğu doğal, kültürel ve tarihi değerlerle rekreasyonel ve turizm amaçlı olarak değerlendirilmektedir. Türkiye'nin ikinci büyük milli parkı olan Beyşehir Gölü Milli Parkı da farklı zenginliklerle birçok insanın ziyaret ettiği yerlerden biridir. Milli parklar rekreasyon ve turizm amacıyla kullanıldığında, kullanıcılara bir maliyet getirmektedir. Seyahat, bir rekreasyonel faaliyet için tamamlayıcı bir nitelik taşımaktadır, çünkü bu faaliyetin gerçekleşebilmesi için söz konusu alana seyahat etmek gerekmektedir. Bu kapsamda, çalışmada Beyşehir Gölü Milli Parkı'nın seyahat maliyeti ve buna etki eden faktörleri incelenmiştir. Beyşehir Gölü Milli Parkı içinde bulunan çeşitli rekreasyon yerleri için ortalama seyahat maliyeti 252.97 TL, kişi başına düşen seyahat maliyeti 74.93 TL olarak hesaplanmıştır. Seyahat maliyetini etkileyen faktörleri incelemek için ziyaretçilerin seyahat maliyetleri yarı logaritmik regresyon modeliyle analiz edilmiştir. Bağımlı değişken seyahat süresince yapılan harcamaların toplamından oluşmakta, seyahat maliyetini etkileyen faktörler olarak, yaş, eğitim, medeni durum, gelir, geliş sıklığı, geliş amacı, geliş mesafesi gibi değişkenler alınmıştır. Analizlerde kullanılan; gelir, eğitim durumu, medeni durumun 'evli" olması, parka bir defadan fazla gelmiş olma, parka gelinen mesafe, parkı ziyaretin esas amaç olması ve parkta geçirilen zaman faktörleri ile seyahat maliyeti arasında pozitif bir ilişki bulunmaktadır. Yaş, parka geliş sıklığı ve parka şahsi araçla ulaşım sağlamış olma faktörleriyle seyahat maliyeti arasında ise negatif bir ilişki tespit edilmiştir. Seyahat maliyeti analizlerinde bu faktörlerin ele alınması rekreasyon amacıyla kullanılan alanların ekonomik anlamda değerlendirilmesinde yarar sağlayacaktır. Bir ülkenin önemli doğal kaynağı olan milli parkların ekonomik olarak ta değerlendirilerek milli gelire katkı sağlaması gerçekleştirilmelidir. Bu amaçla, milli parkları turizm faaliyetleri açısından sürdürülebilir hale getirecek çalışmalar doğayı koruyarak yapılmalıdır. Bu çalışmada tespit edilen seyahat maliyetini etkileyen faktörler de dikkate alınarak ilgili birimler tarafindan programlar planlanmalıdır.

Anahtar Kelimeler: Milli park, Beyşehir, Seyahat maliyeti, Rekreasyon, Turizm

\footnotetext{
1*Sorumlu Yazar/Corresponding Author Zuhal KARAKAYACI, Selçuk Üniversitesi Ziraat Fakültesi Tarım Ekonomisi Bölümü, Konya Türkiye. E-mail: zkarakayaci@gmail.com OrcID: 0000-0003-2933-5608.

2 Özer KARAKAYACI, Konya Teknik Üniversitesi Mimarlık ve Tasarım Fakültesi Șehir ve Bölge Planlama Bölümü, Konya Türkiye. E-mail: karakayaci@ktun.edu.tr (D) OrcID: 0000-0001-9001-4163.

${ }^{3}$ Ahmet Tuğrul POLAT, Selçuk Üniversitesi Mimarlık ve tasarım Fakültesi Peyzaj Mimarlığı Bölümü, Konya Türkiye. E-mail: atpolat@selcuk.edu.tr (D) OrcID: 0000-0002-0980-3243.

Atıf/Citation: Karakayacı Z., Karakayacı Ö., Polat A.T. Beyşehir Gölü Milli Parkında Seyahat Maliyetini Etkileyen Faktörlerin Analizi. Tekirdă̆ Ziraat Fakültesi Dergisi,192 (1), 132-144.

CBu çalışma Tekirdağ Namık Kemal Üniversitesi tarafından Creative Commons Lisansı (https://creativecommons.org/licenses/by-nc/4.0/) kapsamında yayınlanmıştır. Tekirdağ 2022 


\begin{abstract}
National parks are used for recreational and tourism purposes with their natural, cultural and historical values. Turkey's second largest national park, the Beysehir Lake National Park is one of the places visited by many people with different wealth. When national parks are used for recreation and tourism, they bring a cost to the users. Travel carries a complementary quality for a recreational activity, because it is necessary to travel to these areas for realization of these activities. In this context, the travel cost of Beyşehir Lake National Park and the factors affecting it were examined in this study. The average travel cost for various recreation places in the Beyşehir Lake National Park was calculated as 252.97 TL and the per capita travel cost was calculated as 74.93 TL. In order to examine the factors affecting travel costs, travel costs of visitors were analyzed using a semi-logarithmic regression model. The dependent variable consists of the sum of the expenses made during the travel, and variables such as age, education, marital status, income, arrival frequency, arrival purpose and arrival distance were taken as factors affecting travel costs. There is a positive relationship between the factors of income, education, marital status being "married", having been to the park more than once, the distance to the park, the main purpose of visiting the park and the time spent in the park and the travel cost. A negative relationship was found between the age, the frequency of coming to the park and the factors of having access to the park by personal vehicle and the travel cost. Addressing these factors in travel cost analysis will be beneficial in the economic evaluation of the areas used for recreation. National parks, which are an important natural resource of a country, should be economically evaluated and contribute to the national income. For this purpose, activities should be carried out in order to make sustainable the national park in terms of tourism activities by protecting nature. Programs should be planned by the relevant units, taking into account the factors affecting the travel cost determined in this study.
\end{abstract}

Keywords: National park, Beysehir, Travel cost, Recreation, Tourizm 


\section{Giriş}

Sosyal ve ekonomik nedenlerden dolayı kentsel alanlar cazibe merkezi haline gelmiştir. Öte yandan yoğun yapılaşma baskısı altındadır. Kentleşme sürecinde kentsel alanlarda yeşil alan ihtiyacının karşılanması kent ekolojisi ve sosyolojisi açısından önem arz etmektedir (Erduran Nemutlu, 2016). Bununla birlikte, dünyada nüfusun artması ve sanayileşmenin gelişmesiyle doğal kaynakların bilinçsizce kullanımı, bu kaynakların korunması ihtiyacını ortaya çıkarmıştır. Bu kapsamda korumaya alınan doğal kaynakların başında Milli Parklar gelmektedir. Türkiye'deki milli ve milletlerarası değerlere sahip milli park, tabiat parkı, tabiat anıtı ve tabiat koruma alanlarının belirlenmesi, korunması, geliştirilmesi ve yönetilmesi ile ilgili hazırlanan 1983 tarih ve 2873 sayılı Milli Parklar Kanunu kapsamında Milli Park "bilimsel ve estetik bakımından, milli ve milletlerarası ender bulunan tabii ve kültürel kaynak değerleri ile koruma, dinlenme ve turizm alanlarına sahip tabiat parçaları” olarak tanımlanmaktadır. Milli park kavramının ortaya çıkmasına neden olan temel etken doğal, tarihi ve kültürel değerlerin korunması ihtiyacı olmuştur.

Milli parklar doğal bitki örtüsü, biyoçeşitlilik, farklı canlı türleri, jeolojik oluşumlar, tarihi yapılar, arkeolojik yapılar, mimari ve kültürel yapılar itibariyle özgün değere sahip doğal kaynaklardır. Bu yapısı itibariyle ulusal ve uluslararası boyutta rekreasyonel ve turizm amaçlı ilgi görmektedir. Milli parklar, geleneksel olarak doğal alanın korunması ve herhangi bir müdahaleye konu olmaması vurgusu üzerine tanımlanırken, son yıllarda milli parklar yerli ekonomik sürdürülebilirliğini destekleyen önemli bir mekanizma olarak değişim yaşamıştır.

Milli parklar doğa yürüyüşü, bisiklet, dağcılık, piknik, kampçılık gibi birçok rekreasyon faaliyetini içinde barındırmaktadır. Rekreatif faaliyetlerin artmasıyla insanlar mekân tercihlerini de değiştirmeye başlamıştır. Bu değişimler sonucunda doğal ve kültürel değerler bakımından zengin olan milli parklara yönelimler de artmıştır. Dünyadaki birçok ülke bu yönelimleri değerlendirerek turizm etkinliklerini korunmuş alanlara yönlendirmektedir (Öztürk, 2004). Bu kapsamda, turizm amaçlı planlamalarda doğal kaynakların çekicilik özelliği yönlendirici bir rol oynamaktadır (Kiper ve ark., 2011). Rekreasyonel aktiviteleri içerisinde barındıran bu korunan alanlar, insanların kentleşmenin getirdiği yoğun yaşantıdan uzaklaşmasını sağlayarak refah artışını desteklemektedir (Şahbaz ve Altınay, 2015). Önemli destinasyon alanları oluşturan milli parklar doğru şekilde planlanıp yönetildiği takdirde sürdürülebilir turizm faaliyetleri gerçekleştirilerek çeşitli sosyal faydalar sağlamaktadır. Ayrıca ziyaretçi harcamalarından elde edilen kazançlar yöre halkına ve yerel ekonomiye katkıda bulunurken, aynı zamanda yöre halkının parkı benimseyip koruması karşılıklı fayda oluşturmaktadır (Çavuşoğlu ve Varlı, 2007; Şengöz, 2018). Bu kapsamda milli parklar toplum refahının sağlanmasında önemli katkılar sağlamaktadır.

Milli parklar rekreasyon ve turizm amacıyla kullanıldığında, kullanıcılara bir maliyet getirmektedir. Seyahat, bir rekreasyonel faaliyet için tamamlayıcı bir nitelik taşımaktadır, çünkü bu faaliyetin gerçekleşebilmesi için söz konusu alana seyahat etmek gerekmektedir. Bir rekreasyonel alanın değerinin en az ziyaretçinin yaptığı seyahat masraflarına eşit olduğu varsayılmaktadır (Bann, 1998). Bu seyahat masrafları ulaşım masraflarını, giriş ücretlerini, alanda yapılan masrafları ve tüketim gereçleri için harcanan paraları içermektedir. Rekreasyonel bir gezi için harcanan zamanın fursat maliyetinin ve ulaşım giderlerinin, o gezinin seyahat maliyeti olduğu kabul edilmektedir (Ortaçeşme ve ark., 1999). Bir rekreasyon alanını ziyaret eden birey, ziyaret süresi boyunca para kazanmaktan vazgeçmiş durumdadır. Bu nedenle vazgeçilen paranın maliyeti analize dahil edilebilir (Gürlük, 2006). Seyahat Maliyeti; sosyal alanları ziyaret edebilmek için ayrılan zaman ve paranın firsat maliyeti olup, sosyal alanların talep düzeyini ve buna bağlı olarak değerini belirlemek için ziyaret süresinde gerçekleştirilen masrafların toplamına eşittir.

Çalışmada Türkiye'nin ikinci büyük milli parkı olan Beyşehir Gölü Milli Parkı'nın seyahat maliyeti ve buna etki eden faktörleri incelenmiştir. Milli Parkta, yerli ve yabancı turistler için rekreatif faaliyetler; dağ yürüyüşü, kırda gezinti, dağ bisikletiyle gezi ve piknik alanları, jeep safari güzergâhları, çadır ve karavanla kamp yapabilme olanakları bulunmaktadır. Milli Parkta yapılabilen tüm aktiviteler; Olta balıkçılığı, Doğa Yürüyüşü, Çadırlı Kampçılık, Kaya tırmanışı, Bisiklet sporu, Fotoğrafçılık, Yayla Turizmi, Dağcılık, Piknik, Yaban Hayatı Gözlemciliği, Oryantiring (Anonim, 2019). Beyşehir'in turizm potansiyeli açısından bir diğer özelliği ise gün batımıdır. Güneş batarken Anamas Dağı ile Gölün birlikte oluşturduğu olağanüstü görünüm, renk ve batış süresi yönünden dünyada birinci sayılan grup içerisinde yer almaktadır. Beyşehir Gölü, Eşrefoğlu Camii, Karaburun Plajı, Yakamanastır Tabiat Parkı, Leylekler Vadisi, Yeşildağ Kamp Alanı, Kubad-Abad Selçuklu Saray Sitesi, Taş 
Köprü, Beyşehir Kız Kalesi ve Adasını da içinde barındıran milli park birçok ziyaretçi için farklı rekreasyon faaliyetlerine uygun bir alandır.

Çalışma Alanı olan Beyşehir Gölü Milli Parkı Konya ve Isparta illeri sınırları arasında, İç Anadolu Bölgesi ile Toros Dağları arasında bir geçiş alanında yer almakta olup, Konya ili Beyşehir ilçesi sınırları içinde 86.855 hektarlık bir alanda bulunmaktadır. Beyşehir Gölü’nün bir kısmını kaplayan alan 11.01.1993 tarih ve 93/4020 Sayılı Bakanlar Kurulu Kararı ile Milli Park olarak ilan edilmiştir. Ancak, 27.11.2018 tarih ve 30608 Sayılı Resmi Gazete'de çıkan karar ile Milli Park sınırları revize edilmiş ve 82.156,77 hektar olarak değiştirilmiştir (DKMGM, 2019). Milli Park, Türkiye'nin en büyük tatlı su gölü olan Beyşehir Gölü'nün büyük bir bölümünü içine almaktadır. Göl içerisinde irili ufaklı 33 adet ada bulunmaktadır. Bazı adalarda Bizans manastırlarının bulunması inanç turizmi açısından önem kazanmaktadır. Ayrıca Milli Park sınırları içerisinde 588 adet bitki örneği toplanmış, 153 adet kuş türü belirlenmiş olup, ekolojik anlamda oldukça zengin olduğu görülmektedir.

Doğal, tarihi ve kültürel zenginlikleri olan Beyşehir Gölü Milli Parkı'nın mevcut rekreatif potansiyelinin ortaya konulabilmesi amacıyla bu çalışma yapılmışırı. Milli parkların önemli doğal zenginlikler olduğunun farkındalığını oluşturmayı amaçlamanın yanısıra seyahat maliyetini ve etkileyen faktörleri ortaya koyarak ilgili birimlerin bu farkındalığın oluşturulmasında gerçekleştirecekleri projelere yardımcı olmak hedeflenmiş̧ir.

\section{Materyal ve Metot}

Çalışmanın ana materyalini, amaca uygun olarak çalışma alanı olan Beyşehir Gölü Milli Parkı'nı ziyaret eden bireylerle yüz yüze yapılan anketlerden elde edilen veriler oluşturmaktadır. Ayrıca ilgili kamu kurum ve kuruluşlardan elde edilen ikincil verilerden ve konu ile ilgili daha önce yapılmış çalışmalardan yararlanılmıştır.

Seyahat maliyetine etki eden faktörleri incelemek için ziyaretçilerin seyahat maliyetleri yarı logaritmik regresyon modeli ile analiz edilmiştir. Bağımlı değişken seyahat süresince yapılan harcamaların toplamından oluşmakta olup, seyahat maliyetini etkileyen faktörler olarak, yaş, eğitim, medeni durum, gelir, geliş sıklığı, geliş amacı, geliş mesafesi gibi değişkenler alınmıştır. Solikin ve arkadaşları tarafından (2019) Malezya ve Endonezya rekreasyon alanlarında yapılan çalışmada yaş, eğitim, gelir ve ziyaret sayısı seyahat maliyetini etkileyen faktörler olarak belirlenmiştir.

$\mathrm{X}$ ve $\mathrm{Y}$ değişkenlerinden herhangi biri geometrik diğeri de aritmetik seri özelliği taşıyorsa yar1-logaritmik modeller kullanılmaktadır. Bir diğer ifade ile parametreler arası nispi ve mutlak değişmelerin karşılaştırılması ve aralarındaki ilişki tespit edilmek isteniyorsa bu ilişki yarı-logaritmik modeller ile gösterilmektedir. Yarı logaritmik modele ilişkin denklem Eşitlik 1'de gösterilmiştir (Tari, 2010).

$$
\ln Y=b_{0}+b_{1} X_{1}+b_{2} X_{2}+\cdots+b_{n} X_{n}+e
$$

Modelde $b_{0}$ sabit katsayıyı ifade ederken, $b_{1}$ parametresi InY'nin $X^{\prime}$ e göre türevini verirken aynı zamanda $X$ değişkeninde meydana gelen mutlak bir değişmenin $\mathrm{Y}$ değişkeninde meydana getirdiği nispi değişmeyi de göstermektedir (Sarımeşeli, 2000; Yavuz, 2009).

Anket yapılacak örnek sayısının belirlenmesinde Eşitlik 2'den yararlanılmış̧ır. N büyüklüğündeki sonlu bir popülasyon için, populasyonun standart sapması yerine belli bir özelliği taşıyanların bilinen ya da tahmin edilen oranına (p) göre örnek hacmi belirlenmektedir (Oğuz ve Karakayacı, 2017).

$$
n=\frac{N(p . q)}{(N-1) D^{2}+(p q)}
$$

$\mathrm{N}=$ Populasyondaki Birim Sayıs

$\mathrm{n}=$ Örnek Hacmi

$\mathrm{p}=$ İncelenen Olayın Gerçekleşme Olasılı̆̆ 1

$\mathrm{q}=$ İncelenen Olayın Gerçekleşmeme Olasılığı (1-p)

$\mathrm{D}=(\mathrm{d} / \mathrm{t}) \quad \mathrm{d}=$ Kabul edilebilir hata, $\mathrm{t}=$ Belirli bir güven aralı̆̆ 1 için $\mathrm{t}$ değeri

Tarım ve Orman Bakanlı̆ğ Doğa Koruma ve Milli Parklar Genel Müdürlüğü 8. Bölge Müdürlüğü’nün hazırlamış olduğu Konya Doğa Turizmi Master Planına göre Beyşehir Gölü Milli Parkı ziyaretçi sayısı 100.000 olarak belirtilmiş̧ir. Çalışmada, ziyaretçi sayısı popülasyonun birim sayısı olarak kabul edilmiştir. Parkın 
ziyaretinde ücret ödenmesini kabul edenlerin oranı p, kabul etmeyenlerin oranı q olarak ele alınmıştır. Daha önce yapılan araştırmalardan ya da deneyimlerden $p$ oranı hakkında herhangi bir tahmin olmadı̆̆ durumlarda $p$ ve $q$ oranları 0.5 olarak alınabilir (Oğuz ve Karakayacı, 2017). Bu çalışmada da p ve q oranları 0.5 olarak alınmıştır. Beyşehir Gölü Milli Parkı'nın seyahat maliyetini amaçlayan bu çalışmada \%95 güven aralığı ve \% 5 hata payı ile örnek hacmi 383 olarak belirlenmiştir.

\section{Araştırma Sonuçları ve Tartışma}

Beyşehir Gölü Milli Parkı ziyaretçilerinin sosyo-ekonomik ve demografik özellikleri Tablo 1'de verilmiş olup, araştırma kapsamındaki ziyaretçilerin \%73.11'i erkek, \%26.89’u kadınlardan oluşmaktadır. Araştırma alanı olan Beyşehir Gölü Milli Parkı'na gelen ziyaretçilerin çoğunlukla aileleriyle birlikte geldikleri belirlenmiştir.

\section{Tablo 1. Ziyaretçilerin özellikleri}

\section{Table 1. Visitor characteristics}

\begin{tabular}{lcc}
\hline Cinsiyet & Sayı & Oran \\
\hline Erkek & 280 & 73.11 \\
Kadın & 103 & 26.89 \\
Medeni Durum & & \\
Bekâr & 95 & 24.80 \\
Evli & 285 & 74.41 \\
Diğer & 3 & 0.78 \\
Ailedeki Birey Sayısı & & \\
1-3 Kişi & 124 & 32.38 \\
4-6 Kişi & 251 & 65.54 \\
7-9 Kişi & 8 & 2.09 \\
Yaş Grupları & & \\
18-24 Yaş & 51 & 13.32 \\
25-34 Yaş & 112 & 29.24 \\
35-44 Yaş & 120 & 31.33 \\
45-54 Yaş & 54 & 14.10 \\
55-64 Yaş & 32 & 8.36 \\
65+ Yaş & 14 & 3.66 \\
\hline
\end{tabular}

Ziyaretçilerin öğrenim durumu Tablo 2'de verilmiş olup, \%44.13'ü üniversite mezunu ve \%6.01'i lisansüstü eğitime sahip kişilerden oluşurken, \%26'sı lise, \%15.14'ü ilkokul, \%7.31'i ortaokul mezunudur. Ziyaretçilerin gelir durumu belli aralıklarla gruplandırıldığında \%44.65 ile en yüksek oranla 2100-4000 TL aralı̆̆ ve \%32.38 oranla 4100-6000 TL aralığı en büyük paya sahip gelir düzeyleridir. Nijerya'da Milli Parkın seyahat maliyeti ile ilgili yapılmış bir çalışmada (Osunsina ve Ajibola, 2017) ziyaretçilerin \%79'unun 35 yaş altı, öğrenci ve bekar olduğu, tamamının yükseköğretim mezunu olduğu belirlenmiştir.

Elde edilen veriler doğrultusunda, Beyşehir Gölü Milli Parkı ziyaretçilerinin genel profiline bakıldığında erkek, evli, 5 kişilik ailede yaşayan, 40 yaşında, üniversite mezunu ve $4000 \mathrm{TL}$ aylık gelire sahip olduğu belirlenmiştir.

Milli parkı ziyaret eden bireylerin \%33'ü kendilerine ait bir evde ikamet ederken, \%67'si kiracı olarak ikamet etmektedir. Ayrıca ziyaretçilerin \%66'sının evi bahçesizken, \%34'ü bahçeli bir evde ikamet etmektedir. Bu oranlar yeşil alan ihtiyacı duyan kişilerin milli park ve benzeri alanları tercih ettiği çıkarımı ile örtüşmektedir.

Araştırma sahasında bulunan ziyaretçilerin \%83'ü Konya ilinde ikamet etmektedir. Konya ilini \%4 pay ile Antalya, \%2'şer pay ile Ankara ve İzmir takip etmektedir. Ulaşılan sonuçlar ve anket esnasında edinilen bilgiler doğrultusunda Beyşehir Gölü Milli Parkı'nın yöresel olarak faaliyet gösterdiği belirlenmiş, bu duruma; uzak mesafeden ziyaretçi çekebilecek ölçüde tanınmaması, sahip olduğu değerlerin (yeşil alan dışında tarihi yapılar ve kamp, bisiklet, festival gibi faaliyetler) farkında olunmaması neden gösterilebilmektedir. 


\section{Tablo 2. Ziyaretçilerin öğrenim ve gelir durumu}

Table 2. Education and income status of visitors

\begin{tabular}{lcc}
\hline Öğrenim Durumu & Sayı & Oran \\
\hline Okur-Yazar & 2 & 0.52 \\
İlkokul & 58 & 15.14 \\
Ortaokul & 28 & 7.31 \\
Lise & 103 & 26.89 \\
Üniversite & 169 & 44.13 \\
Lisansüstü & 23 & 6.01 \\
Gelir Durumu & & \\
$1000-2000 \mathrm{TL}$ & 26 & 6.79 \\
$2100-4000 \mathrm{TL}$ & 171 & 44.65 \\
$4100-6000 \mathrm{TL}$ & 124 & 32.38 \\
$6100-8000 \mathrm{TL}$ & 32 & 8.36 \\
$8100-10000 \mathrm{TL}$ & 18 & 4.70 \\
$10000+$ TL & 12 & 3.13 \\
\hline
\end{tabular}

Ziyaretçilerin \% 40’ının Beyşehir Gölü Milli Parkına yedi kez ve daha fazla kez geldikleri belirlenmiştir. Bu oran ziyaretçilerin \%83'lük kısmının parkın yakın çevresinden gelmesi ile ilişkilendirilebilmektedir. \%24'lük oran parka ilk kez gelen ziyaretçilere ve \%23'lük oran ise 1-3 kez gelen ziyaretçilere aittir (Şekil 1).

Ziyaretçilerin \%38'inin milli parka yılda iki seferden daha fazla geldiği ve \%35'inin yılda bir kez ziyarette bulunduğu sonucuna ulaşılmıştır. \%19'luk oran ise yılda iki kez ziyarette bulunan kişilere aittir (Şekil 2). Milli park sınırlarının yerleşim birimi içerisinde yer alması, ziyaret sıklığının nedeni olarak gösterilebilir.

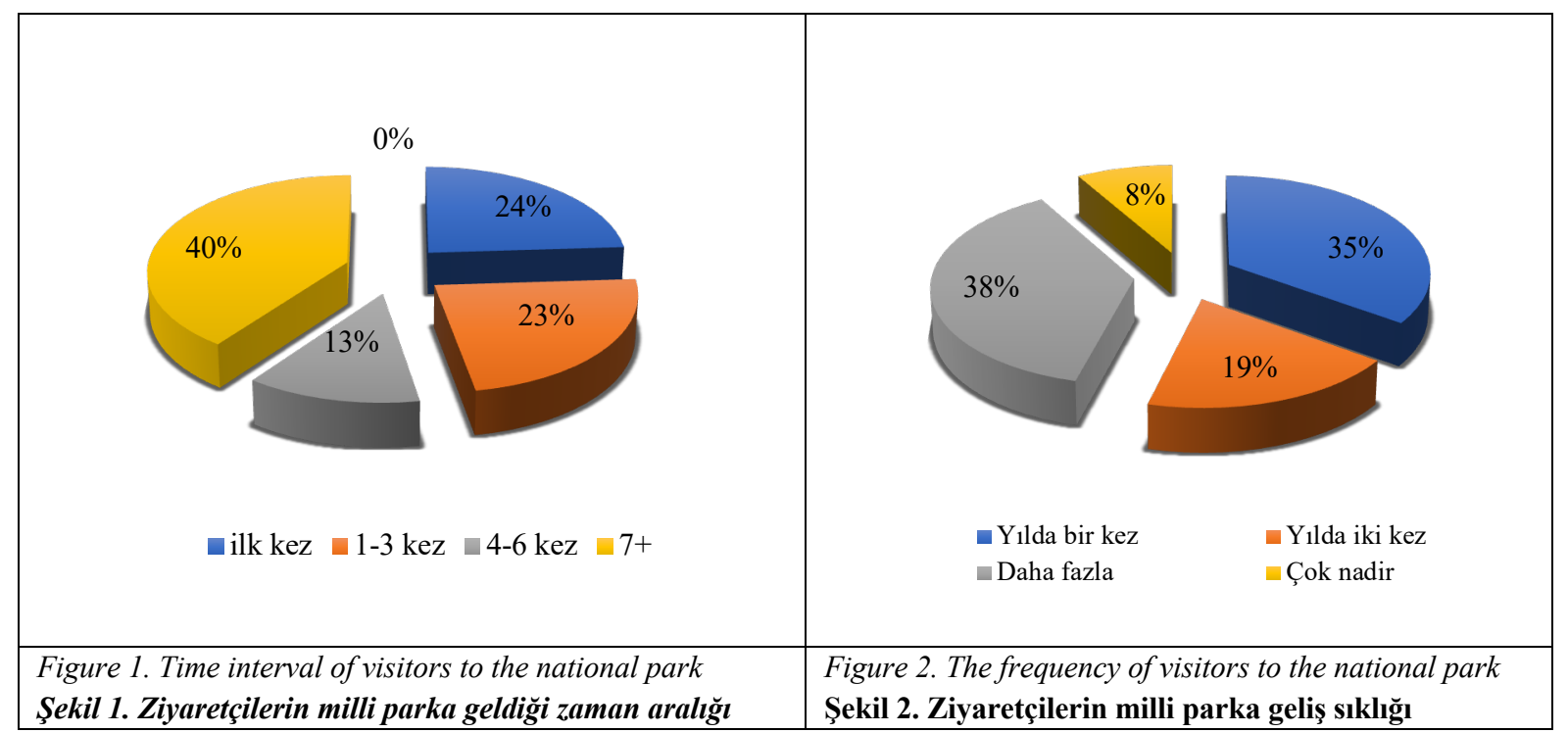

Ziyaretçilerin \%90’ının Beyşehir Gölü Milli Parkına daha sık gelmeye istekli olduğu sonucuna ulaşılmıştır. Araştırmada yer alan ziyaretçilerin \%92'sinin çevrelerine milli parkı önerecekleri \%8'inin ise önermeyecekleri sonucuna ulaşılmıştır.

Ziyaretçilerin \%46's1 51-100 km mesafeden, \%19'u 101-200 km mesafeden, \%15'i 0-30 km mesafeden, $\% 12$ 'si $200 \mathrm{~km}$ ve üzeri mesafeden ve \%8'i 31-50 km mesafeden parka ulaşım sağlamıştır. Ziyaretçilerin milli parka ulaşım süreleri ortalaması 1.68 saat ve geldikleri mesafe ortalama 75 km olarak hesaplanmıştır. \% 64'lük oranla 51-100 km arası mesafe Konya ili merkez ilçelerden gelen ziyaretçilerin oluşturduğu orandır. Ziyaretçilerin \%90’ının milli parka kendi araçları ile ulaşım sağladığı görülmektedir. 


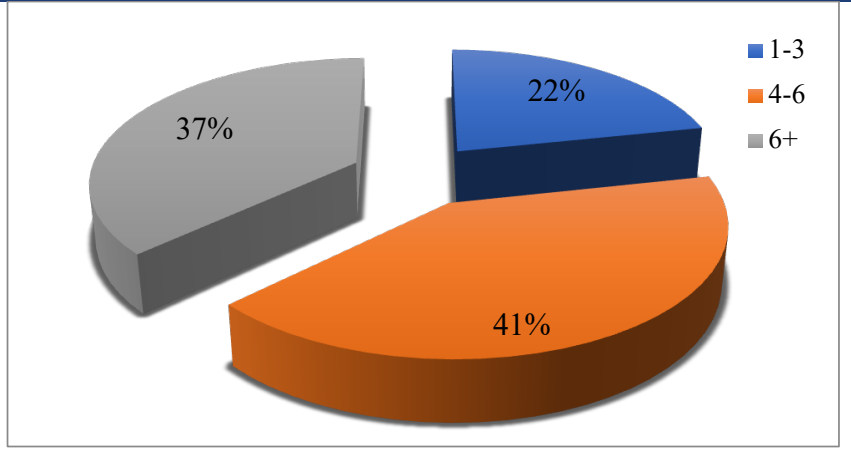

Figure 3. The number of people with whom the visitors come to the national park Şekil 3. Ziyaretçilerin milli parka birlikte geldikleri kişi sayısı

Beyşehir Gölü Milli Parkını ziyaret eden kişiler \%41'lik oranla 4-6 kişilik gruplardan oluşurken, \%37'si 6 ve üzeri kişilik, \%22'si 1-3 kişilik gruplarla ziyaretlerini gerçekleştirmiştir (Şekil 3). 4-6 ve 6 üzeri aralığının çok daha yüksek çıkması anket çalışmalarının \%35.51'inin piknik alanı ve \%27.94'ünün göl sahilinde yapılmış olmasıyla bağdaştırılmıştır. Ziyaretçilerin \%62'si Beyşehir Gölü Millî Parkına aile bireyleriyle gelirken, \%33’ü akrabalarıyla gelmeyi tercih etmiştir. Tur şirketleri ile gelen ziyaretçi oranının oldukça düşük olduğu görülmektedir.

Ziyaretçilerin Beyşehir Gölü Milli Parkında geçirdikleri ortalama saat 9.8'dir. Ortalama, Beyşehir Gölü Milli Parkının içinde barındırdığı ve farklı saat dilimlerinin geçirilebileceği alanlarda (piknik alanı, kamp alanı, tarihi alanlar ve sahil) yapılan anketler sonucunda hesaplanmıştır. Geçirilmesi planlanmış en kısa süre göl iskelesinde gezinti yapan bir ziyaretçiye ait yarım saatlik zaman dilimidir. En uzun dilim ise 61 gün Milli park sınırlarında bulunan kamp alanında konaklamayı planlamış ziyaretçiye aittir.

Milli parkın ilgi çeken değerleri incelendiğinde \%49 oranıyla en çok ilgi çeken unsurun göl olduğu sonucuna ulaşılmıştır. Diğer değerler ise \%31 ile bitki örtüsü, \%12 ile tarihi değerler, $\% 4$ ile yaban hayatı ve yine \%4 ile jeolojik yapı olarak sıralanmıştır. Seyahat maliyetinin belirlenebilmesi için parka ulaşım masrafları, yanında getirdikleri için yapılan masraflar ve park içerisinde yapılan masraflar toplanmıştır. Buna göre ortalama seyahat maliyeti 252.97 TL olarak belirlenmiştir (Şekil 4).

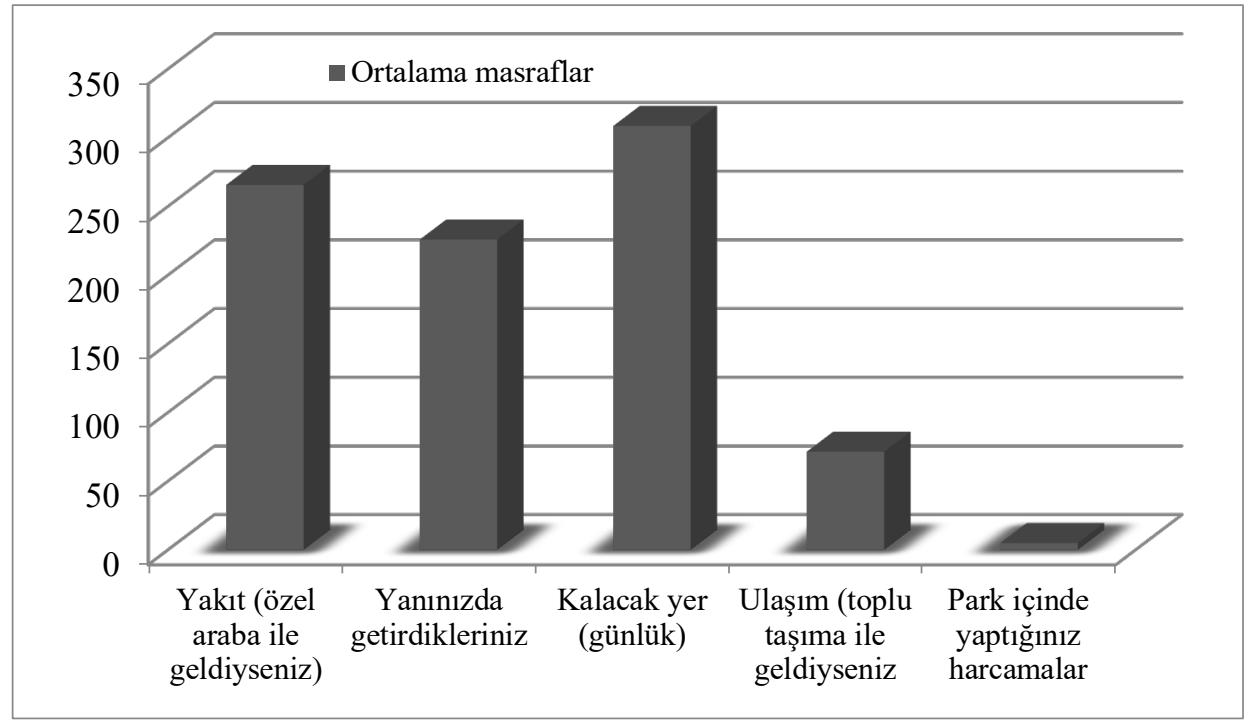

Figure 4. Visitors' average expenses during the trip

\section{Şekil 4. Ziyaretçilerin gezi boyunca ortalama masraflart}

Kişi başına düşen seyahat maliyetini tespit etmek için ise toplam seyahat maliyeti ziyaretçi grubunda bulunan birey sayısına bölünmüştür. Kişi başına düşen seyahat maliyeti 74.93 TL olarak belirlenmiştir. Kişi başına düşen 
seyahat maliyetinin düşük çıkmasının nedeni Milli Park ziyaretçilerinin büyük oranda Beyşehir ilçesinden ve Konya ili yakın ilçelerinden geldiğinden ve grup sayılarının fazla olmasından kaynaklanmaktadır. Nitekim Nijerya'da yapılan çalışmada da (Osunsina ve Ajibola, 2017) milli parka yakınlığın ziyaret oranını artırdığı, yüksek maliyetin ziyaret sayısını azalttığı sonucuna varılmıştır.

Beyşehir Gölü Milli Parkı sınırları içerisinde yer alan belirli noktalarda araştırma yoğunlaştırılmış olup, bu noktalara göre seyahat maliyetindeki değişim ortaya konulmuştur. Bu noktalar Eflatun Pınarı, Eşrefoğlu Cami, İskele, Kamp Alanı, Karaburun Plajı, Leylekler Vadisi, Sonsuz Şükran Köyü ve Yakamanastır Piknik Alanı olup, tarihi, kültürel, doğa turizmi olarak farklılık göstermektedir.

Eflatun Pınarı ve Sonsuz Şükran Köyü revizyon yapılmadan önce milli parkın sınırları içerisinde yer almakta iken, mevcut sınırları içerisinde bulunmadığı halde araştırma alanına dahil edilmiştir. Çünkü bu noktalar Beyşehir Gölü Milli Parkı ile özdeşleşmiş olup, milli parkı ziyarete gelen insanların buraları da ziyaret ettikleri görülmektedir. Beyşehir Gölü Milli Park ziyaret yerleri içerisinde en fazla masrafın yapıldığı yer kamp alanı (532 TL) olarak belirlenmiştir (Tablo 3). Bunun nedeni, kamp alanında kalınan gün sayısının 2 gün ile 2 ay arasında değişmesidir. Eşrefoğlu Camisi Beyşehir ilçesi merkezinde yer almakta olup, yol masrafının da toplam masrafın da yüksek olmasının nedeni, ziyaret amacının esas amaç olmasından kaynaklanması ve ilçe dışından ziyaretçi sayısının fazla olmasındandır. En düşük masrafın ise İskele'de yapıldığı görülmektedir.

Tablo 3. Ziyaret yerlerine göre seyahat maliyeti

Table 3. According to the travel cost places to visit

\begin{tabular}{lcc}
\hline Ziyaret Yeri & Yol Masrafi (TL) & Toplam Masraf (TL) \\
\hline Eflatun Pınarı & 78 & 179 \\
Eşrefoğlu Cami & 184 & 319 \\
İskele & 80 & 126 \\
Kamp Alanı & 94 & 532 \\
Karaburun Plajı & 92 & 250 \\
Leylekler Vadisi & 150 & 350 \\
Sonsuz Şükran Köyü & 102 & 229 \\
Yakamanastır Piknik Alanı & 88 & 285 \\
\hline
\end{tabular}

Seyahat maliyetini etkileyen faktörlerin analizinde bağımlı değişken seyahat süresince yapılan harcamaların toplamından oluşmaktadır. Tahmin edilen seyahat maliyeti modelinin bağımsız değişkenler tarafından açıklanma gücü olan $\mathrm{R}^{2} \% 49.2$ olarak belirlenmiştir. Bu değer istatistiki olarak \% 1 önem seviyesinde anlamlı bulunmuştur. $\mathrm{R}^{2}$ 'ye (\% 49) göre bağımlı değişkende meydana gelen değişmelerin \% 49'u bağımsız değişkenler tarafindan açıklanmaktadır (Tablo 4). Seyahat maliyetindeki değişmelerin yaklaşık \% 51'i modelde yer almayan ve açıklanamayan değişkenler tarafından gerçekleşmektedir. Seyahat maliyeti için tahmin edilen modelin dw istatistiği 1.73 olup kritik değerlere göre $(\mathrm{dl}=1.46, \mathrm{du}=1.90)$ model için otokorelasyon kararsız bölgede belirlenmiş̧ir. Ancak otokorelasyon yatay kesit verileri ile yapılan analizlerde parametrelerin güvenilirliğini etkilemez. Bununla birlikte otokorelasyon parametresi ( $\mathrm{dw}$ ) kararsız bölgede belirlendiğinde alternatif yöntemlerle otokorelasyon varlığı araştırılır. Bu alternatiflerden birisini Gujarati önermiş̧tir (Gujarati, 1999). Öneriye göre du kritik değerini dikkate alarak Ho hipotezini test etmektir. Kararsız bölgedeki bir otokorelasyon parametresi için temel kriter du olarak alınır ve ho hipotezi red edilir. Ayrıca modelde yer alan değişkenlerin tamamı için varyans büyütme faktörü (VIF) belirlenmiş ve çoklu bağlantı problemi olmadığı tespit edilmiş̧ir. Modelde değişen varyans problemi araştırılmıştır. Buna göre ( $\mathrm{p}$ value $<0.05$ ) değişen varyans problemi olmadığ belirlenmiştir. Model bu sonuçlara göre istatistiki ve ekonometrik olarak kullanılabilir ve sonuçların tutarlı ve etkin olduğu söylenebilir.

Seyahat maliyetini açıklamak için Beyşehir Gölü Milli Parkını ziyaret edenlerin demografik özellikleri, ziyaret faktörleri ve ziyaret yerlerinin özellikleri kullanılmıştır. Demografik faktörler olarak gelir, eğitim, yaş ve medeni durum değişkenleri modele dâhil edilmiştir. Gelir değişkeninin seyahat maliyeti üzerindeki etkisi pozitif olarak belirlenmiş olup istatistiki olarak \% 1 önem seviyesinde anlamlı bulunmuştur.

Yarı logaritmik modellerde değiş̧enlere ait parametreler matematiksel modelin kalıbına göre farklı yorumlanmaktadır. Bu çalışmada bağımlı değişkenin logaritması alınmıştır. Bağımsız değişkende meydana gelen 
birim değişme bağımlı değişkeni parametre kadar oransal değiştirmektedir (Yayar ve Karaca, 2014; Güriş ve Akay, 2018).

Gelir değişkeni gruplandırılarak modele dâhil edilmiş olup her bir gelir grubuna göre seyahat maliyetindeki artış \% 3.6 olarak belirlenmiştir. Nitekim bu bulgu iktisadi teori açısından da anlamlıdır. Gelir-tüketim elastikiyeti pozitif olup gelir artışı kültürel harcamaları da beraberinde artırmaktadır. Bölgenin turizm gelirlerini artırmak amacıyla bu değişkenin sonuçları anlamlı olarak belirlenmiştir. Yüksek gelir gruplarının ilgisini çekecek turizm faaliyetlerinin düzenlenmesi önemlidir. Bu bağlamda Beyşehir Gölü Milli Parkı için turistik tanıtım faaliyetleri içerisinde yüksek gelirli gruplara ulaşılması ve buna göre programların hazırlanması gerekliliği ortaya çıkmaktadır.

Modelde yer alan diğer bir değişken eğitim olup seyahat maliyeti üzerindeki etkisi pozitif olarak belirlenmiş ve bu değişkene ait katsayısı istatistiki olarak \% 1 önem seviyesinde anlamlı bulunmuştur. Eğitim değişkeni modele mezun olunan okul seviyesine göre dâhil edilmiştir. Buna göre eğitim seviyesi arttıkça seyahat maliyetlerinin \% 3.5 olarak artacağı belirlenmiştir. Nitekim Beyşehir Gölü Milli Parkı sosyal ve kültürel amaçlı turistik alandır. Kültür turizmleri ile eğitim arasında yüksek bir korelasyon beklenmektedir. Buna göre eğitim seviyesinin artması kültürel alanların ziyaret sıklığını ve sayısını artırmakta ve bu durum seyahat maliyetlerine yansımaktadır. Kültür turizmi açısından Eşrefoğlu Camii, Eflatun Pınarı ve diğer kültür mirası alanların eğitimli gruplara tanıtımının bölgenin turizm gelirini artırmak açısından önemli olduğu söylenebilir.

Seyahat maliyetini etkileyen diğer bir faktör yaş değişkenidir. Ziyaretçilerin yaşlarının da seyahat maliyetlerini etkilediği belirlenmiştir. Ziyaretçilerin yaş gruplarındaki artışın seyahat maliyetini negatif etkilediği tespit edilmiştir. Bu değişkenin seyahat maliyetini etkilemesi istatistiki olarak \% 10 önem seviyesinde anlaml bulunmuştur. Bu sonuca göre yaşlı nüfusun daha az harcama yaptığı belirlenmiştir. Yaşlı ziyaretçiler yakın mesafeden gelmekte ve ulaşım, konaklama ve diğer masraflar biraz daha az olmaktadır. Bu durum Ki kare analizi ile de test edilmiş (Chi-square:210) ve yaş değişkeni ile mesafe arasındaki ilişki \% 1 önem seviyesinde istatistiki olarak anlamlı bulunmuştur. Elde edilen bu sonuca göre Beyşehir Gölü Milli Parkı tanıtımlarında gençlere öncelik verilmelidir. Ayrıca gençler için sosyal ve kültürel aktiviteler, mekânlar ve diğer faaliyetlere önem verilmesi bölgenin turizm gelirlerini artıracaktır.

Ziyaretçilerin medeni durumunun seyahat maliyetlerini etkileyeceği düşünülerek modele dâhil edilmiştir. Bu değişkene ait katsayı pozitif olarak belirlenmiş olup \% 1 önem seviyesinde istatistiki olarak anlamlı bulunmuştur. Medeni durum değişkeni evli (1) ve bekâr (0) olarak modele alınmıştır. Elde edilen parametreye göre evli ziyaretçilerin bekâr olanlara göre \% 8.9 oranında daha yüksek harcama yaptıkları belirlenmiştir. Ailece yapılan harcamaların daha fazla olması beklenen bir durumdur. Milli park içerisinde aileye yönelik konaklama, yemek, gezi ile birlikte diğer sosyal ve kültürel faaliyetlerin artırılması turizm gelirlerini artıracaktır.

Modelde yer alan diğer bir değişken grubu ise ziyaret faktörleridir. Ziyaret ile ilgili faktörlerin de seyahat maliyetini etkileyeceği düşünülmektedir. Bunlardan birincisi ziyaretçilerin Geliş yılı olarak tanımlanmış olup, ziyaretçilerin kaç yıldır Beyşehir Gölü Milli Parkı'nı ziyaret etmeye geldiklerini açıklamaktadır. Bu değişkenin seyahat maliyeti üzerindeki etkisi pozitif olarak belirlenmiş ve \% 5 önem seviyesinde istatistiki olarak anlamlı bulunmuştur. Daha uzun yıllar Milli Parkı ziyarete gelenlerin harcamalarının daha fazla olduğu her yıl için harcama artışının ise \% 2.5 olduğu belirlenmiştir. Bu parametre ile Milli Parkın ziyaretçileri cezbedici olduğu, onların güzel vakit geçirebildiklerini ve tekrar gelmek için donatıların olduğunu açıklamaktadır. Bu sonuçtan yola çıkarak ziyaretçilerin gelişlerini tekrarlayacak sosyal donatıların artırılmasının turizm gelirlerini artırmak açısından önemli olduğu söylenebilir.

Modelde yer alan diğer bir değişken ise Ziyaret Sıklığı olarak kabul edilmiştir. Ziyaretçilerin belirli bir zaman diliminde ne kadar sıklıkla geldiğini açıklamaktadır. Bu değişkene ait katsayı negatif olarak belirlenmiştir. Ayrıca istatistiki olarak \% 10 önem seviyesinde anlamlı bulunmuştur. Gelme sıklığındaki artışın ziyaret başına harcamaları \% 2.7 oranında azalttığı belirlenmiştir. Sık gelen ziyaretçilerin genel olarak Beyşehir Gölü Milli Parkına yakın yerlerden geldiği ve ulaşım, konaklama, yemek ve diğer harcamalarının daha az olduğu düşünülmektedir. Nitekim ziyaret sıklığı ile mesafe arasındaki ilişki Ki-Kare (Chi-square:113) analiziyle test edilmiş ve \% 1 önem seviyesinde istatistiki olarak anlamlı bulunmuştur. Alan çalışmaları süresince yapılan gözlemler bu sonuçları doğrulamaktadır. Yakın mesafeden gelen ziyaretçilerin özellikle park alanlarında fazla 
harcama yapılmayan öğünlük yemek organizasyonu yaptıkları gözlenmiş̧ir. Yakın bölgede yaşayanlar Beyşehir Gölü Milli Parkı özelliklerini bilmekte ve kullanmaktadırlar. Bu kullanım sıklı̆ı̆ı artırmak ve yerel turizm potansiyelini geliştirmek için günü birlik kullanım alanlarını ve bölge insanına yönelik her mevsimin özelliklerine göre faaliyetlerin artırılması önemli görülmektedir.

Seyahat maliyetini etkileyen diğer bir faktör ise ziyaretçilerin bu parkı ziyaret etmek için geldikleri mesafedir. $\mathrm{Bu}$ parametrenin seyahat maliyeti üzerindeki etkisi pozitif olarak belirlenmiştir. Ziyaret mesafesi arttıkça birim başına seyahat maliyetinin \% 10.8 oranında arttığı belirlenmiş̧tir. Bu etki \% 1 önem seviyesinde istatistiki olarak anlamlı bulunmuştur. Seyahat mesafesinin uzamasının seyahat maliyetine pozitif etkisi anlamlı bulunmuştur. Nitekim seyahat masrafları seyahat maliyetinin bir bileşenidir. Seyahat masraflarının içerisinde yakıt ile birlikte toplu taşıma kullananlar için bilet ücretleri yer almaktadır. Bu durumda seyahat mesafesinin uzamaması seyahat maliyetini artıracaktır. Seyahat maliyetinin artması Beyşehir Gölü Milli Parkı ziyaret talebine olumsuz yansıyacaktır. Özellikle büyükşehirlerde seyahat acenteleri ile anlaşmalı olarak toplu organizasyon paketleri hazırlanmalı ve tanitımları yapılmalıdır.

Ziyaretçilerin Beyşehir Gölü Milli Parkına gelme amaçlarının da seyahat maliyetini etkileyeceği varsayılmaktadır. Bu amaca yönelik olarak ziyaretçilerin Beyşehir Gölü Milli Parkını ziyaretlerinin temel amaç olup olmadığı anket uygulaması aşamasında belirlenmiş̧tir. Seyahat başlangıç amacı Milli Parkı ziyaret olanlar için "1" ve diğerleri için "0" değeri verilerek kategorik değişken olarak modele dâhil edilmiş̧ir. Bu değişkenin seyahat maliyeti üzerindeki etkisi pozitif olarak belirlenmiş olup, istatistiki olarak \% 5 önem seviyesinde anlamlı bulunmuştur. Bu sonuçlara göre seyahat başlangıç amacı Beyşehir Gölü Milli Parkı ziyareti olan ziyaretçilerin diğerlerine göre \% 10.1 daha fazla harcama yaptıkları belirlenmiştir. Diğer ziyaretçilerin genel olarak Beyşehir Gölü Milli Parkının yol güzergâhında olması nedeniyle ziyaret ettikleri belirlenmiş olup, ziyaretçiler bu amaçla iki grupta değerlendirilmiştir. Ancak her iki grubun Milli Parkı ziyareti seyahat maliyeti ve bölgenin turizm geliri açısından önemlidir. Bu amaca yönelik olarak her iki grup ziyaretçilere yönelik faaliyetler, sosyal donatılar, ulaşım imkânları ve diğer faktörler geliştirilmelidir.

Seyahat maliyetini etkileyen en önemli faktörlerden biri seyahat aracı olarak düşünülerek modele dâhil edilmiştir. Nitekim bölgeden veya bölge dışından Milli Parkı ziyaretleri özel araçlar, toplu taşıma araçları ve farklı alternatiflerle olabilmektedir. Bu amaçla ulaşım araçları kendi araçları, kiralık araçlar, bireysel toplu taşıma araçları ve tur araçları olarak sınıflandırılmıştır. Bu değişkenin seyahat maliyeti üzerine etkisi negatif olarak belirlenmiş̧ir. Elde edilen sonuçlara göre kendi araçları ile gelenlerin harcamalarının daha yüksek olduğu belirlenmiş̧ir. Değişkene ait katsayı \% 1 önem seviyesinde istatistiki olarak anlamlı bulunmuştur. Kendi aracıyla veya kiralık araçla gelenlerin seyahat maliyetleri yüksek belirlenmiştir. Bu harcamalar ulaşım maliyetlerinden kaynaklanmaktadır. Ulaşım maliyetlerinin yüksek olması Milli Park gezi talebini olumsuz etkileyebilir. Toplu ziyaret organizasyonlarının düzenlenerek tanıtımının yapılması önemlidir.

Modelde yer alan diğer bir değişken ise ziyaretçilerin Milli Parkta geçirdikleri zamandır. Ziyaret aşamasında zamanın uzaması seyahat harcamalarını artıracağı düşünülmektedir. Bu amaca yönelik olarak saat birimi ile zaman değişkeni modele dâhil edilmiştir. Zaman değişkeninin seyahat maliyeti üzerindeki etkisi pozitif olarak belirlenmiş̧tir. Ayrıca değiş̧ene ait katsayı \% 1 önem seviyesinde istatistiki olarak anlamlı bulunmuştur. Bu değişkenin seyahat maliyeti üzerindeki pozitif etkisi beklenen bir sonuçtur. Ziyaret zamanının uzaması konaklama, yemek ve diğer aktivitelere yapılan harcamaları artıracaktır. Bu amaca yönelik olarak ziyaretçilerin ziyaret saatlerini uzatabilecek faaliyet ve amaçların oluşturulması turizm geliri açısından önemlidir.

Beyşehir Gölü Milli Park alanında bulunan ziyaret yerlerine göre seyahat maliyetinin değişeceği düşünülerek her bir ziyaret yeri DUMMY değişkeni ile temsil edilerek modele dâhil edilmiştir. Milli Park alanı içerisinde yer alan ziyaret yerleri Kamp alanı, Eflatun pınarı, İskele, Karaburun Plajı, Sonsuz Şükran Köyü, Yaka Manastır ve Eşrefoğlu Camisi olarak belirlenmiş ve bu ziyaret yerlerinde ziyaretçiler ile anket uygulaması yapılmıştır. Ziyaret yerlerinin özellikleri birbirinden farklıdır. Böylece seyahat maliyetinin değişkenlik göstereceği düşünülmektedir. Nitekim Eşrefoğlu Camii, Eflatun Pınarı ve Sonsuz Şükran Köyü kültürel bir ziyaret alanı olup, Yaka Manastır, Kamp Alanı, İskele ve Karaburun Plajı ise sosyal mekânlardır. DUMMY değişkeni gözlem sayısının bir eksiği kadar modelde yer alabilmektedir. Ayrıca bir değişkeni referans alarak diğerleri ile karşılaştırma yapılmaktadır. $\mathrm{Bu}$ modelde Eşrefoğlu Camii seyahat maliyetleri referans değeri olarak kabul edilmiş ve diğerleri için parametre belirlenmiş̧tir. Kamp alanındaki ziyaretçilerin referans ziyaret yeri olan Eşrefoğlu Camii ziyaretçilerine göre \% 15 
Karakayacl \& Karakayacı \& Polat Beyşehir Gölü Milli Parkında Seyahay Maliyetini Etkileyen Faktörlerin Analizi daha fazla harcama yaptıkları belirlenmiş olup, bu değer \% 5 önem seviyesinde istatistiki olarak anlamlı bulunmuştur.

Tablo 4. Seyahat Maliyetini Etkileyen Faktörlerin Analizi

Table 4. Analysis of Factors Affecting Travel Costs

\begin{tabular}{|c|c|c|c|c|c|c|}
\hline \multirow{2}{*}{$\begin{array}{l}\text { Değişken } \\
\text { grupları }\end{array}$} & Değişkenler & Katsayılar & $\begin{array}{l}\text { Katsayıların } \\
\text { Standart Hatası }\end{array}$ & $\begin{array}{l}\text { T } \\
\text { istatistiği }\end{array}$ & $\begin{array}{l}\text { Önem } \\
\text { Düzeyi }\end{array}$ & VIF \\
\hline & Sabit Katsayı & 1.525 & .121 & 12.559 & .000 & \\
\hline \multirow{4}{*}{$\begin{array}{l}\text { Demografik } \\
\text { Özellikler }\end{array}$} & Gelir & .036 & .010 & 3.549 & .000 & 1.200 \\
\hline & Eğitim & .035 & .012 & 2.805 & .005 & 1.384 \\
\hline & Yaş & -.021 & .011 & -1.875 & .062 & 1.385 \\
\hline & Medeni Durum & .089 & .031 & 2.903 & .004 & 1.229 \\
\hline \multirow{6}{*}{$\begin{array}{l}\text { Ziyaret } \\
\text { Faktörleri }\end{array}$} & Geliş Y1lı & .025 & .012 & 2.077 & .039 & 1.311 \\
\hline & Ziyaret Sıklığı & -.027 & .014 & -1.937 & .054 & 1.272 \\
\hline & Geliş Mesafesi & .108 & .012 & 8.787 & .000 & 1.215 \\
\hline & Geliş Amacı & .101 & .042 & 2.431 & .016 & 1.058 \\
\hline & Ulaşım Aracı & -.054 & .016 & -3.401 & .001 & 1.163 \\
\hline & Geçirdiği Zaman & $5.394 \mathrm{E}-06$ & .000 & 3.131 & .002 & 1.080 \\
\hline \multirow{6}{*}{$\begin{array}{l}\text { Ziyaret } \\
\text { Yerleri }\end{array}$} & Kamp Alanı & .153 & .064 & 2.382 & .018 & 3.056 \\
\hline & Eflatun Pınarı & -.178 & .099 & -1.793 & .074 & 1.421 \\
\hline & İskele & -.239 & .065 & -3.690 & .000 & 2.725 \\
\hline & Karaburun Plajı & .078 & .060 & 1.299 & .195 & 1.384 \\
\hline & $\begin{array}{l}\text { Sonsuz Şükran } \\
\text { Köyü }\end{array}$ & -.180 & .108 & -1.671 & .096 & 1.385 \\
\hline & Yaka Manastır & .060 & .058 & 1.027 & .305 & 4.468 \\
\hline
\end{tabular}

Karaburun plajı \% 7.8 ve Yaka Manastır \% 6 Eşrefoğlu camisi ziyaretçilerine göre daha fazla harcama yaptıkları belirlenmiştir. Eflatun Pınarı (\% 17), İskele (\% 23) ve Sonsuz Şükran köyü (\% 18) ziyaretçileri ise Eşrefoğlu camisi ziyaretçilerine göre daha az harcama yaptıkları belirlenmiştir. İskele haricindeki sosyal alanlarda ziyaretçiler kültürel alanlara göre daha fazla harcama yapmaktadırlar. Bu sonuca göre sosyal alanların ziyaretçileri cezbetme potansiyelinin yüksek olduğu anlamına gelmektedir. Sosyal alanların fazla ve yüksek faaliyet içermesi turizm gelirlerini artırma açısından önemli görülmektedir.

Ayrıca kültürel alanların sosyal alanlara göre daha az ilgi çekmesi veya daha az harcama yapılması ziyaretçilerin eğitim seviyesi ile açıklanabilir. Ayrıca ziyaretçilerin eğitim seviyelerinin karşılaştırılması ile birlikte dünya miraslarını içerisinde barındıran Türkiye'nin yerli ve yabancı turizminin istenilen seviyede olmamasını da açıklamaktadır. Özellikle kültürel miras yapıları taşra bölgelerinde zengin bir biçimde yer almaktadır. Kırsal turizmle birlikte desteklenmesinin yerli ve yabancı turizm gelirini artıracağı düşünülmektedir. Nitekim kültürel turizm ile eğitim seviyesi arasında bir ilişki olduğu bilinmekte olup, bu çalışma için eğitim ve ziyaret yerleri arasındaki ilişki Ki Kare analizi ile test edilmiş (Chi-square:253) olup \% 1 önem seviyesinde istatistiki olarak anlamlı bulunmuştur.

Milli parklarda yapılan ekonomik çalışmalar, doğal kaynakların sürdürülebilirliğini ve koruma planlarını sağlamak için sosyal ve ekonomik yöneticilere yol gösterici niteliktedir (Pirikiya ve ark., 2016). Araştırma alanı olan Beyşehir Gölü Milli Parkı'nın mevcut potansiyeli hakkında farkındalık oluşturabilmek için ilgili birimlerin turizm potansiyelini artırmak, ulusal ve uluslararası daha fazla tanınırlığını sağlamak için gerekli düzenlemeleri yapması gerekmektedir. Milli parkların yönetiminde, bu alanlar için ayrılan bütçelerde seyahat maliyeti analizlerinin katkı sağlayacağı düşünülmektedir. Bazı çalışmalarda (Solikin ve ark., 2019; Osunsina ve Ajibola, 2017) milli parkların korunması ve böylece toplumun faydasının artması için milli park giriş ücretlerinin artırılması gerektiği önerilmektedir. Bu tür önlemler, korunan alanları daha değerli kılacak ve önemini artıracaktır. 


\section{Sonuç}

Milli parklar, doğal yapının korunması ile çevresel bir role sahipken, yerel ve buna bağlı olarak ülkesel ekonominin sürdürülmesinde de etkin pay almaktadır. Doğal yapısının yanında kültürel ve tarihi yapıları içermesi turizm potansiyeli açısından ön plana çıkmaktadır. Bu yönüyle toplumun refah düzeyini artırıcı sosyal fayda sağlamakta olup, ekonomik anlamda değerlendirilmesi gereken doğal kaynaklardır.

Çalışmada, rekreasyon ve turizm amacıyla kullanılan ve çok çeşitli aktivite potansiyeline sahip Beyşehir Gölü Milli Parkı'nı ziyaret için yapılan seyahat maliyeti hesaplanmış ve etkileyen faktörler analiz edilmiştir. Beyşehir Gölü Milli Parkı içinde bulunan çeşitli rekreasyon yerleri için ortalama seyahat maliyeti 252.97 TL, kişi başına düşen seyahat maliyeti 74.93 TL olarak hesaplanmıştır. Seyahat maliyetini etkileyen faktörler yarı logaritmik regresyon modeli ile analiz edilmiştir. Analizlerde kullanılan; gelir, eğitim durumu, medeni durumun ''evli', olması, parka bir defadan fazla gelmiş olma, parka gelinen mesafe, parkı ziyaretin esas amaç olması ve parkta geçirilen zaman faktörleri ile seyahat maliyeti arasında pozitif bir ilişki bulunmaktadır. Yaş, parka geliş sıklığı ve parka şahsi araçla ulaşım sağlamış olma faktörleriyle seyahat maliyeti arasında ise negatif bir ilişki tespit edilmiştir. Ayrıca milli park sınırları içerisindeki sosyal alanların seyahat maliyetinin kültürel alanlara göre fazla olduğu, bu nedenle sosyal alanların daha fazla getiri sağladığı ve sağlayabilecek olduğu sonucuna ulaşılmıştır. Bu sonuçlardan yola çıkarak her bir unsur üzerinden Beyşehir Gölü Milli Parkının gelişimi ve sürdürülebilirliği açısından politikalar geliştirmek mümkün hale gelmiştir. Milli Parkın mevcut yapısına uygun doğa sporlarının yaygınlaştırılması, ekoturizm faaliyetlerinin artırılması, Milli Park çevresindeki kırsal ekonomiyi kalkındırma adına faaliyetlerin yürütülmesi gibi uygulamaları geliştirmeye yönelik politikalar gerçekleştirilmelidir.

Araştırma bulguları sonucu sağlanmış edinimlere göre, Beyşehir Gölü Milli Parkı ülkemiz milli parkları içinde tarihi, doğal ve sosyal değerleri bir arada barındıran yüksek turizm potansiyeline sahip bir milli parktır. Ancak bu potansiyel tam anlamıyla değerlendirilememekte ve parkın değerleri sürdürülebilir olarak kullanılamamaktadır. Milli parkın korunması ve tanıtılması için yöre halkının bu doğrultuda bilinçlendirilmesi en büyük gerekliliklerden bir tanesidir.

Beyşehir Gölü Milli Parkının katı bir anlayışla korunması, turizme yönelik gelişmeleri kısıtlamaktadır. Bu nedenle, Beyşehir yerleşmesinin milli parktan sosyal ve ekonomik anlamda faydalanabilmesi için yenilikçi ve uygulanabilir bir yönetişim sisteminin kurulması kaçınılmazdır. Bunun için tüm Beyşehir’de tüm paydaşların ortak hedef çerçevesinde işbirliği yapacağı bir mekanizmanın geliştirilmesi gerekmektedir. Bölgede yerel kaynakları harekete geçirecek çeşitli projelerin ortaya konulması ve sosyal-beşeri sermaye potansiyelini arttırmaya yönelik çabalar, milli parkın yerel kalkınma için önemli bir unsura dönüştürülme sürecinde aşılmaz görünen işbirliğine karşı çok sayıda engel ortadan kalabilecektir.

\section{Teşekkür}

Bu çalışma TÜBİTAK tarafından desteklenen 218K315 numaralı projeden türetilmiştir. Desteklerinden dolayı TÜBİTAK'a teşekkür ederiz. 


\section{Kaynakça}

Anonim, (2019). https://www.beysehirto.org.tr/cografyasi/

Bann, C., (1998). The Economic Valuation of Tropical Forest Land Use Options: A Manual for Researchers. Economy and Environment Program for Southeast Asia Report Series.

Çavuşoğlu, M., Varlı, R. (2007). Ekoturizm ve Bayramiç Yöresine Yönelik Yeni Bir Tanıtım Stratejisi, Bayramiç Sempozyumu, Çanakkale

DKMGM, (2019). Doğa Koruma ve Milli Parklar Genel Müdürlüğü, http://www.milliparklar.gov.tr/korunan-alanlar/milli-parklar

Erduran Nemutlu, F. (2016). Çanakkale 500. yıl parkının peyzaj tasarımı ve sosyo-kültürel olanakları açısından irdelenmesi, Tekirdă̆ Ziraat Fakültesi Dergisi, 13(3): 48-59.

Güriş, S., Akay-Çağlayan, E. (2018). Ekonometri Temel Kavramlar. Sf.290, 5.Baskı, Der Yayınları, İstanbul.

Gujarati, D.N. (1999). Temel Ekonometri, Literatür Yayıncılık, İstanbul.

Gürlük, S. (2006). Manyas Gölü ve Kuş Cenneti’nin çevresel değerlemesi üzerine bir araştırma. (Doktora Tezi) Uludağ Üniversitesi Fen Bilimleri Enstitüsü Tarım Ekonomisi Anabilim Dalı,. Bursa:

Kiper, T., Özyavuz, M., Korkut, A. (2011). Doğal peyzaj özelliklerinin kırsal turizm gelişimine etkisi: Tekirdağ İli Şarköy İlçesi örneği, Tekirdă̆ Ziraat Fakültesi Dergisi, 8(3): 22-34.

Oğuz, C., Karakayacı, Z. (2017). Tarım Ekonomisinde Araştırma ve Örnekleme Metodolojisi, As Atlas Akademi, Konya.

Ortaçeşme, V., Özkan, B., Karagüzel, O. (1999). Kurşunlu Şelalesi Tabiat Parkının Ekonomik Değerinin Saptanması, TÜBİTAK Proje No: 25, Antalya.

Osunsina, I.O.O, Ajibola, K.T. (2017). Travel cost anaylsis of tourist visits to Okomu National Park, Nigeria.Nigerian Journal of Wildlife Management, 1(1), 111-116.

Öztürk, S. (2004). Çevre Sorunlarına Çağdaş Yaklaşımlar, Beta Basım Yayım Dağıtım A.Ş.,İstanbul.

Pirikiya, M., Amirnejad, H., Oladi, J., Ataie Solout, K. (2016). Determining the recreational value of forest park by travel cost method and defining its effective factors, Journal of Forest Science, 62(9), 399-406.

Sarımeşeli, M. (2000). Ekonometri El Kitabı. Birinci Baskı, Gazi Kitabevi Ankara.

Solikin, A., Rahman, R.A., Saefrudin, E., Suboh, N., Zahari, N.H., Wahyudi, E. (2019). Forest valuation using travel cost method (TCM): cases of Pahang national park and Srengseng Jakarta urban forest. Journal of Malaysian Institute of Planner, 17(1),365-376.

Şahbaz, R. P., Altınay, M. (2015). Türkiye'deki milli parkların rekreasyon faaliyetleri açısından değerlendirilmesi. Journal of Tourism and Gastronomy Studies, 3(3), 125-135.

Tari, R. (2010). Ekonometri. Umuttepe Yayınları, Kocaeli.

Şengöz, Ş. (2018). Sürdürülebilir turizm kapsamında Dikili’nin ekoturizm potansiyelinin incelenmesi. (Yüksek Lisans Tezi) İzmir Katip Çelebi Üniversitesi Fen Bilimleri Enstitüsü, Ekoturizm Anabilim Dalı, İzmir.

Yavuz, S. (2009). Regresyon analizinde doğrusala dönüştürme yöntemleri ve bir uygulama, Ataturk University Journal of Economics \& Administrative Sciences, 23(1),165-179.

Yayar, R., Karaca, S.S. (2014). Konut fiyatlarına etki eden faktörlerin hedonik modelle belirlenmesi: TR83 bölgesi örneği, Ege Akademik Baklş, 14(4), 509-518. 